\title{
ANALISIS PERHITUNGAN DAN PELAPORAN PAJAK PENGHASILAN PASAL 21 WAJIB PAJAK ORANG PRIBADI PADA BADAN PENGELOLA KEUANGAN DAN ASET DAERAH KOTA MANADO
}

\author{
Yeremia Gosal $^{1}$, Herman Karamoy ${ }^{2}$, Jessy Warongan ${ }^{3}$ \\ ${ }^{1,2,3}$ Fakultas Ekonomi dan Bisnis. Jurusan Akuntansi. Universitas Sam Ratulangi, Jl. Kampus Bahu, Manado, \\ 95115, Indonesia. \\ E-mail : alexandergosa@gmail.com
}

\begin{abstract}
This study aims to determine the calculation and reporting of income tax article 21 permanent employee at the Regional Finance and Asset Management Board (BPK-AD) Manado City and comparing with the Minister of Finance Regulation no. 101 / PMK.010/2016 and Regulation of the Director General of Taxation Number: PER - 31 / PJ / 2012. Non-Taxable Income (PTKP) is a deduction in the calculation of income tax article 21. As for the increase of PTKP this causes the tax burden becomes even less zero, for individual taxpayer. The research method used is qualitative research using interview technique and documentation observation. Next describe the data received and present it in accordance with the actual situation. The result of the research shows that the calculation of Income Tax Article 21 individual taxpayer by BPK-AD of Manado City is not in accordance with Law Number 36 Year 2008 because the amount inputted has excess number which can cause Income Tax 21 increased; The determination of non-taxable income (PTKP) is in conformity with Regulation of the Minister of Finance no. 101 /PMK.010/2016; The reporting of PPh 21 employees, conducted through e-filling at the latest end of April, but not in accordance with tax regulations.
\end{abstract}

Keywords: Calculation, Reporting, and Income Tax Article 21.

\section{PENDAHULUAN}

Sebagai pendapatan negara, pajak berfungsi untuk membiayai pengeluaranpengeluarannya. Pengeluarannya adalah bersifat umum seperti belanja rumah tangga negara, yakni pengeluaran yang bermanfaat bagi masyarakat luas. Manfaat pajak merupakan akibat dari pemungutan pajak. Mardiasmo (2016: 6), "memungut pajak berarti menarik daya beli dari rumah tangga masyarakat untuk rumah tangga negara. Selanjutnya negara akan menyalurkannya kembali ke masyarakat dalam bentuk pemeliharaan kesejahteraan masyarakat”. Dengan demikian negara memiliki hak untuk memungut pajak.

Salah satu pelaksanaan pemungutan pajak yang digunakan untuk membiayai rumah tangga negara, yakni pajak penghasilan. Undang-undang Pajak Penghasilan ( $\mathrm{PPh}$ ) mengatur tentang pengenaan pajak penghasilan dari penghasilan yang diterima oleh subjek pajak dalam satu tahun pajak. Undang-undang tentang pajak penghasilan diatur dalam UU No. 7 Thn 1984, yang telah beberapa kali diubah dan terakhir kali diubah dengan Undang-undang nomor 36 tahun 2008.

Perkembangan pajak di Indonesia terus mengalami perubahan dari waktu ke waktu. Perubahan itu tentunya diikuti oleh perkembangan ekonomi, teknologi, sosial dan politik sehingga dibuat peraturan atau ketentuan-ketentuan yang baru tentang pajak. Ketentuan yang baru tentu dibuat untuk maksud yang baik, baik untuk negara maupun untuk rakyatnya. 
Berdasarkan pertimbangan dari perkembangan di bidang ekonomi dan harga kebutuhan pokok yang semakin meningkat, akhirnya pemerintah menetapkan peraturan menteri keuangan tentang penyesuaian besarnya penghasilan tidak kena pajak. Peraturan Menteri Keuangan No. 101 /PMK.010/2016 ditetapkan pada tanggal 22 Juni 2016 dan mulai berlaku untuk tahun pajak 2016. Penghasilan Tidak Kena Pajak (PTKP) merupakan pengurang dalam perhitungan pajak penghasilan. Besarnya PTKP yang baru ini naik menjadi Rp4.500.000,00 (empat juta lima ratus ribu rupiah) per bulan untuk wajib pajak orang pribadi. Kenaikkan ini tentu juga diikuti oleh pertumbuhan ekonomi dan pembangunan nasional yang semakin berkembang.

Badan Pengelola Keuangan dan Aset Daerah (BPK-AD) Kota Manado adalah pelaksana urusan pemerintahan lingkup pengelolaan keuangan dan aset daerah. Sebagai salah satu Perangkat Daerah (PD) Kota Manado, BPK-AD juga memiliki kontribusi dalam penerimaan negara yaitu dalam bentuk pembayaran pajak penghasilan pasal 21 oleh pegawai. Dalam perhitungan PPh 21 pegawai, diperoleh dari hasil penginputan daftar gaji ke dalam suatu sistem dengan menggunakan bantuan komputer. Sistem penginputan ini dilakukan oleh pegawai bagian keuangan. Terkadang ada ketidaksesuaian antara daftar gaji dengan hasil penginputan untuk memperoleh PPh 21 pegawai BPK-AD Manado. Setelah melakukan perhitungan, selanjutnya adalah penyetoran PPh 21 oleh bendahara pemegang kas pemerintah daerah. Setelah penyetoran, selanjutnya pegawai melaporkan SPT melalui e-filling. Dalam pelaporan pajak penghasilan pasal 21 ini, pegawai sering melebihi batas waktu yang ditetapkan dalam peraturan perpajakan. Berdasarkan hal tersebut, maka penulis tertarik untuk meneliti dalam bentuk skripsi yang berjudul: "Analisis Perhitungan dan Pelaporan Pajak Penghasilan Pasal 21 Wajib Pajak Orang Pribadi Pada Badan Pengelola Keuangan dan Aset Daerah Kota Manado". Tujuan dari penelitian ini yaitu mengetahui perhitungan pajak penghasilan pasal 21 pegawai tetap pada Badan Pengelola Keuangan dan Aset Daerah (BPKAD) Kota Manado dan membandingkan dengan Peraturan Menteri Keuangan No. 101 /PMK.010/2016 tentang penyesuaian besarnya Penghasilan Tidak Kena Pajak (PTKP); dan membandingkan dengan Peraturan Direktur Jenderal Pajak Nomor : PER - 31/PJ/2012 tentang pedoman teknis tata cara penyetoran dan pelaporan pajak penghasilan pasal 21 sehubungan dengan pekerjaan, jasa, dan kegiatan orang pribadi.

\section{TINJAUAN PUSTAKA}

\subsection{Pengertian Akuntansi Perpajakan}

Menurut Sadeli (2016: 6), menyatakan bahwa "Akuntansi perpajakan meliputi penyusunan surat pemberitahuan pajak (SPT), serta mempertimbangkan konsekuensi perpajakan dari transaksi usaha yang direncanakan atau mencari alternatif pelaksanaan terbaik".

\subsection{Pengertian Pajak}

Menurut Undang-Undang No. 28 tahun 2007, pajak adalah kontribusi wajib kepada negara yang terutang oleh orang pribadi atau badan yang bersifat memaksa berdasarkan Undang-Undang, dengan tidak mendapatkan imbalan secara langsung dan digunakan untuk keperluan negara bagi sebesar-besarnya kemakmuran rakyat. Dengan demikian pajak merupakan penerimaan negara dan kewajiban bagi setiap wajib pajak.

\subsection{Sistem Pemungutan Pajak}

Sistem pemungutan pajak menurut Sumarsan (2014: 14) dapat dibagi menjadi: 
1. Official Assessment System. Adalah suatu sistem pemungutan yang memberi wewenang kepada pemerintah (fiskus) untuk menentukan besarnya pajak yang terutang. Ciri-ciri Official Assessment System:

a) Wewenang untuk menentukan besarnya pajak terutang berada pada fiskus;

b) Wajib pajak bersifat pasif [dalam hal menghitung besarnya pajak terutang];

c) Utang pajak timbul setelah dikeluarkan surat ketetapan pajak oleh fiskus.

2. Self Assessment System. Adalah suatu sistem pemungutan pajak yang memberi wewenang, kepercayaan, tanggung jawab kepada wajib pajak untuk menghitung, memperhitungkan, membayar, dan melaporkan sendiri besarnya pajak yang harus di bayar.

3. Withholding System. Adalah suatu sistem pemungutan pajak yang memberi wewenang kepada pihak ketiga [bukan fiskus ataupun Wajib Pajak yang bersangkutan] untuk memotong atau memungut besarnya pajak yang terutang oleh Wajib Pajak.

\subsection{Pajak Penghasilan}

Berikut adalah pengertian penghasilan menurut UU No.36 tahun 2008, yang dimuat dalam pasal 4 ayat 1 :

"Yang menjadi objek pajak adalah penghasilan, yaitu setiap tambahan kemampuan ekonomis yang diterima atau diperoleh Wajib Pajak, baik yang berasal dari Indonesia maupun dari luar Indonesia, yang dapat dipakai untuk konsumsi atau untuk menambah kekayaan Wajib Pajak yang bersangkutan, dengan nama dan dalam bentuk apa pun”.

\subsubsection{Pajak Penghasilan Pasal 21}

Pajak Penghasilan pasal 21 adalah pajak atas penghasilan berupa gaji, upah, honorarium, tunjangan, dan pembayaran lain dengan nama dan dalam bentuk apa pun sehubungan dengan pekerjaan atau jabatan, jasa, dan kegiatan yang dilakukan oleh orang pribadi. Sebagaimana dimaksud dalam pasal 21 undang-undang pajak penghasilan.

\subsubsection{Pemotong Pajak PPh Pasal 21}

Pemotong pajak Dalam Peraturan Direktur Jenderal Pajak Nomor: PER-16/PJ/2016, yaitu:

a. Pemberi kerja yang terdiri dari:

1) Orang pribadi;

2) Badan; atau

3) Cabang, perwakilan, atau unit, dalam hal yang melakukan sebagian atau seluruh administrasi yang terkait dengan pembayaran gaji, upah, honorarium, tunjangan, dan pembayaran lain adalah cabang, perwakilan, atau unit tersebut.

b. Bendahara atau pemegang kas pemerintah;

c. Dana pensiun;

d. Orang pribadi yang melakukan kegiatan usaha atau pekerjaan bebas serta badan yang membayar:Honorarium, komisi, atau pembayaran lain sebagai imbalan sehubungan dengan jasa yang dilakukan oleh orang pribadi dengan status subjek pajak dalam negeri atau subjek pajak luar negeri;

e. Penyelenggara kegiatan.

\subsubsection{Perhitungan PPh Pasal 21 atas Penghasilan Teratur bagi Pegawai Tetap}

Dalam lampiran Peraturan Direktur Jenderal Pajak Nomor: PER-16/PJ/2016, petunjuk umum perhitungan PPh Pasal 21 atas penghasilan teratur bagi pegawai tetap adalah sebagai berikut: 
a. Untuk menghitung PPh pasal 21 atas penghasilan Pegawai Tetap, terlebih dahulu dihitung seluruh penghasilan bruto yang diterima atau diperoleh selama sebulan, yang meliputi seluruh gaji, segala jenis tunjangan dan pembayaran teraturr lainnya, termasuk uang lembur dan pembayaran sejenisnya.

b. Untuk perusahaan yang masuk program Badan Penyelenggara Jaminan Sosial (BPJS) Ketenagakerjaan, premi Jaminan Kecelakaan Kerja (JKK), premi Jaminan Kematian (JK), dan premi Jaminan Pemeliharaan Kesehatan yang dibayar oleh pemberi kerja, merupakan penghasilan bagi pegawai. Ketentuan yang sama diberlakukan juga bagi premi asuransi kesehatan, asuransi kecelakaan kerja, asuransi jiwa, dan asuransi beasiswa yang dibayarkan oleh pemberi kerja untuk pegawai kepada perusahaan asuransi lainnya. Dalam menghitung PPh Pasal 21, premi tersebut digabungkan dengan penghasilan bruto yang dibayarkan oleh pemberi kerja kepada pegawai.

c. Selanjutnya dihitung jumlah penghasilan neto sebulan yang diperoleh dengan cara mengurangi penghasilan bruto sebulan dengan biaya jabatan, serta iuran pensiun, iuran Jaminan Hari Tua (JHT), dan/atau iuran Tunjangan Hari Tua yang dibayar sendiri oleh pegawai yang bersangkutan melalui pemberi kerja kepada Dana Pensiun atau Kepada Badan Penyelenggara Jaminan Sosial Ketenagakerjaan.

d. Selanjutnya dihitung penghasilan neto setahun, yaitu jumlah penghasilan neto sebulan dikalikan 12.

e. Dalam hal seorang pegawai tetap dengan kewajiaban pajak subjektifnya sebagai Wajib Pajak dalam negeri sudah ada sejak awal tahun, tetapi mulai bekerja setelkah bulan Januari, maka penghasilan neto setahun dihitung dengan mengkalikan penghasilan neto sebulan dengan banyaknya bulan sejak pegawai yang bersangkutan mulai bekerja sampai dengan bulan Desember.

f. Selanjutnya dihitung Penghasilan Kena Pajak sebagai dasar penerapan Tarif Pasal 17 Undang-Undang Pajak Penghasilan, yaitu sebesar Penghasilan neto setahun, dikurangi dengan PTKP.

g. Setelah diperoleh PPh terutang dengan menerapkan Tarif Pasal 17 UU PPh terhadap Penghasilan Kena Pajak, selanjutnya dihitung PPh pasal 21 sebulan, yang harus dipotong dan/atau disetor ke kas negara, yaitu sebesar: Jumlah PPh Pasal 21 setahun atas penghasilan dibagi dengan 12; atau Jumlah PPh Pasal 21 setahun atas penghasilan, dibahagi banyaknya bulan yang menjadi faktor pengali.

\subsection{Tarif Pajak}

Tarif pajak berdasarkan UU No.36 Tahun 2008 tentang pajak penghasilan dalam pasal 17, yang diterapkan atas penghasilan kena pajak bagi wajib pajak orang pribadi dalam negeri adalah sebagai berikut:

Tabel 1 Tarif Pajak Penghasilan
\begin{tabular}{|l|l|}
\hline Lapisan Penghasilan Kena Pajak & Tarif Pajak \\
\hline Sampai dengan Rp50.000.000,00 & $5 \%$ \\
\hline $\begin{array}{l}\text { Di atas Rp50.000.000,00 sampai dengan } \\
\text { Rp250.000.000,00 }\end{array}$ & $15 \%$ \\
\hline $\begin{array}{l}\text { Di atas Rp250.000.000,00 sampai dengan } \\
\text { Rp500.000.000,00 }\end{array}$ & $25 \%$ \\
\hline Di atas Rp500.000.000,00 & $30 \%$ \\
\hline
\end{tabular}

Sumber: www.online-pajak.com 


\subsection{Penghasilan Tidak Kena Pajak}

Dalam menghitung besarnya Penghasilan Kena Pajak dari wajib pajak orang pribadi dalam negeri diberikan pengurangan berupa Penghasilan Tidak Kena Pajak (PTKP). Berdasarkan Peraturan Menteri Keuangan Nomor 101/PMK.010/2016 tentang penetapan penghasilan tidak kena pajak yang berlaku mulai tahun pajak 2016 adalah sebagai berikut:

Tabel 2 Penghasilan Tidak Kena Pajak

\begin{tabular}{|l|l|}
\hline Status Wajib Pajak & PTKP Setahun \\
\hline Tidak Kawin (TK) & Rp54.000.000,00 \\
\hline Kawin (K/0) & Rp58.500.000,00 \\
\hline Kawin Anak Satu (K/1) & Rp63.000.000,00 \\
\hline K/2 & Rp67.500.000,00 \\
\hline K/3 & Rp72.000.000,00 \\
\hline
\end{tabular}

Sumber: Peraturan Menteri Keuangan No. 101 /PMK.010/2016

\subsection{Surat Pemberitahuan (SPT)}

Suharsono (2014: 83), mendefinisikan Surat Pemberitahuan/SPT adalah surat yang oleh Wajib Pajak digunakan untuk melaporkan penghitungan dan/atau pembayaran pajak, objek pajak dan/atau bukan objek pajak, dan/atau harta dan kewajiban sesuai dengan ketentuan peraturan perundang-undangan perpajakan.

\subsubsection{Batas Waktu Penyampaian SPT}

Menurut Lubis (2014: 19) menyatakan bahwa "PPh Pasal 21 dibayar paling lambat tanggal 10 bulan berikutnya menggunakan SSP (Surat Setoran Pajak), PPh Pasal 21 dilaporkan paling lambat tanggal 20 bulan berikutnya menggunakan SPT Masa PPh 21. Terlambat lapor PPh Pasal 21 dikenakan denda Rp100.000,00". Denda yang dikenakan termasuk dalam sanksi administrasi. Batas waktu pelunasan pajak yang terhutang penyampaian pelaporan SPT untuk Masa Pajak yang berbeda adalah sebagai berikut:

\section{Tabel 3 Batas Waktu Penyampaian SPT}

\begin{tabular}{|l|l|l|l|}
\hline No. & \multicolumn{1}{|c|}{ Uraian } & \multicolumn{1}{|c|}{ Bayar/Setor } & \multicolumn{1}{|c|}{ Lapor } \\
\hline 1. & PPh Masa Pasal 21/26 & $\begin{array}{l}\text { paling lambat } \\
\text { tanggal 10 bulan } \\
\text { takwim berikutnya } \\
\text { setelah Masa Pajak } \\
\text { berakhir. }\end{array}$ & $\begin{array}{l}\text { paling lambat 20 } \\
\text { hari setelah Masa } \\
\text { Pajak berakhir }\end{array}$ \\
\hline 2. & PPh Tahunan Pasal 21/26 & $\begin{array}{l}\text { sebelum SPT } \\
\text { tahunan } \\
\text { disampaikan. PPh }\end{array}$ & $\begin{array}{l}\text { akhir bulan ketiga } \\
\text { setelah berakhirnya } \\
\text { tahun atau bagian } \\
\text { tahun pajak. }\end{array}$ \\
\hline
\end{tabular}

Sumber: Sumarsan (2014)

\subsection{Penelitian Terdahulu}

1. Puspita (2013) dengan judul analisis perhitungan, pemotongan, penyetoran dan pelaporan pajak penghasilan pasal 21 di PT. Surabaya Inn Berkarya. Tujuan penelitian untuk menguji secara empiris, dan menganalisa mengenai kesesuaian peraturan perpajakan dengan yang terjadi sebenarnya pada perusahaan atas pajak penghasilan pasal 21. Metode 
yang digunakan analisis deskriptif kualitatif. Hasil penelitian dalam perhitungan pajak penghasilan pasal 21 di PT. Surabaya Inn Berkarya telah sesuai dengan ketentuan peraturan perpajakan yang berlaku, dilihat dari perbandingan perhitungan yang dilakukan. peneliti sebelumnya melakukan penelitian terhadap faktor yang sama yaitu penghitungan dan pelaporan pajak penghasilan pasal 21. Peneliti sebelumnya melakukan penelitian terhadap objek lingkup perusahaan, sedangkan peneliti menggunakan objek pemerintahan.

2. Pangalila (2016) dengan judul analisis Penghitungan dan Pelaporan Pajak Penghasilan Pasal 21 Pegawai Badan Pelayanan Perizinan Terpadu dan Penanaman Modal Daerah (BPPT \& PMD) Kota Bitung. Tujuan penelitian ini yaitu untuk menganalisis kesesuaian penghitungan dan pelaporan pajak penghasilan pasal 21 atas gaji pegawai BPPT\&PMD kota Bitung dengan UU No.36 Tahun 2008 dan Peraturan Menteri Keuangan No. 101 /PMK.010/2016. Metode penelitian yaitu Deskriptif-Kuantitatif. Hasil penghitungan PPh Pasal 21 pada pegawai BPPT \& PMD kota Bitung telah sesuai dengan Undang Undang No 36 Tahun 2008 dan prosedur yang diatur dalam Peraturan Perpajakan yang berlaku di Indonesia, Pelaporan Pajaknya juga telah sesuai dengan Undang Undang No 36 Tahun 2008, Penetapan Penghasilan Tidak Kena Pajak (PTKP) yang diterapkan oleh Badan Pelayanan Perizinan Terpadu dan Penanaman Modal Daerah (BPPT \& PMD) kota Bitung belum sesuai dengan peraturan Menteri Keuangan No. 101/PMK/.010/2016. Persamaan dalam penelitian ini yaitu menguraikan penghitungan dan pelaporan Pajak Penghasilan Pasal 21 disesuaikan dengan Peraturan Menteri Keuangan No. 101/PMK.010/2016. Perbedaan dalam penelitian ini yaitu terletak pada objek tempat penelitian, yaitu peneliti menelti pegawai pada Badan Pengelola Keuangan dan Aset Daerah Kota Manado.

\section{METODE PENELITIAN}

\subsection{Jenis Penelitian}

Jenis penelitian adalah kualitatif. Metode penelitian kualitatif adalah metode penelitian yang melibatkan analisis data berupa deskripsi. Jenis penelitian ini berupaya untuk mentransformasi objek penelitian ke dalam bentuk yang dapat dipresentasikan, seperti catatan lapangan (field note), hasil interview, percakapan, foto-foto, rekaman, dan memo (Indrawati, 2015: 206).

\subsection{Tempat dan Waktu Penelitian}

Penelitian ini dilakukan pada Badan Pengelola Keuangan dan Aset Daerah (BPK-AD) Kota Manado yang berlokasi di Jalan Balai Kota nomor 1 Tikala dan penelitian dilaksanakan pada Mei 2017 sampai dengan Agustus 2017.

\subsection{Metode Pengumpulan Data}

\subsubsection{Jenis Data}

Data dikumpulkan dalam penelitian untuk mengetahui masalah apa yang ada dalam data tersebut. Adapun data yang digunakan dalam penelitian ini yakni:

1. Data kualitatif, merupakan data yang berbentuk uraian atau penjelasan dan diperoleh dari hasil wawancara dengan pegawai pada Badan Pengelola Keuangan dan Aset Daerah (BPK-AD) Kota Manado. Data kualitatif dalam penelitian ini berupa gambaran umum tentang BPK-AD Manado.

2. Data kuantitatif, merupakan data yang biasa berbentuk angka dan tabel. Data kuantitatif digunakan dalam penelitian ini berupa data kualitatif yang dikuantifikasikan dengan menggunakan tabel yang diperoleh dari BPK-AD Manado. Jenis data kuantitatif yang dipakai dalam penelitian ini berupa data gaji pegawai tetap tahun 2017 


\subsubsection{Sumber Data}

Sumber data yang digunakan dalam penelitian ini yaitu:

1. Data Primer, data yang diperoleh langsung dari BPK-AD Kota Manado yang diperoleh dengan wawancara.

2. Data Sekunder, berupa dokumen dan catatan yang dibutuhkan dalam penelitian ini. Data diperoleh dari pegawai bagian keuangan.

\subsubsection{Teknik Pengumpulan Data}

1. Wawancara

2. Dokumentasi

\subsection{Metode Analisis}

Menurut Dantes (2012: 51), dalam bukunya menyatakan bahwa "penelitian deskriptif diartikan sebagai suatu penelitian yang berusaha mendeskripsikan suatu fenomena/peristiwa secara sistematis sesuai dengan apa adanya". Metode analisis yang digunakan yakni metode deskriptif analisis yaitu penelitian yang bertujuan untuk memaparkan dan menggambarkan keadaan yang jelas dari objek yang diteliti berdasarkan analisis data yang dikumpulkan sehingga dapat ditarik kesimpulan. Dalam hal ini penelitian bertujuan untuk memberikan penjelasan tentang sistem perhitungan dan pelaporan pajak penghasilan pasal 21 pada Badan Pengelola Keuangan dan Aset Daerah Kota Manado, menggambarkan secara jelas sistem yang diterapkan tersebut sehingga didapatkan hasil oleh data yang telah dianalisis.

\section{HASIL ANALISIS DAN PEMBAHASAN}

\subsection{Hasil Penelitian}

\subsubsection{Perhitungan Pajak Penghasilan Pasal 21}

Berdasarkan hasil penelitian, perhitungan pajak penghasilan pasal 21 diperoleh dari dokumen formulir 1721 yang digunakan pegawai untuk menyetor pajak. Penetapan $\mathrm{PPh} 21$ ini diperoleh dari penginputan data oleh pegawai bagian keuangan ke aplikasi yang diberikan dari kantor pajak. Berikut adalah mekanisme perhitungan pajak penghasilan pasal 21 oleh BPK-AD Manado:

Tabel 5

Perhitungan PPh 21 Pegawai Tetap

BPK-AD Manado Ibu Ing, K/2

\begin{tabular}{|l|r|r|}
\hline \multicolumn{3}{|c|}{ Perhitungan PPh 21 oleh BPK-AD Manado } \\
\hline penghasilan: & Rp 35.417.200 & \\
\hline gaji pokok & 3.541 .720 & \\
\hline tunjangn istri/smi & 1.416 .688 & \\
\hline tunjangan anak & 2.405 .000 & \\
\hline tunj. Fung. Umum & 3.476 .160 & \\
\hline tunj. Beras & 450.424 & \\
\hline tunj. Lain-lain & & 46.707 .192 \\
\hline penghasilan bruto & & \\
\hline pengurangan: & 2.335 .360 & \\
\hline biaya jabatan & 1.917 .841 & \\
\hline Iuran pension & & 42.453 .991 \\
\hline penghasilan neto setahun & & 67.500 .000 \\
\hline PTKP & & \\
\hline penghasilan kena pajak & & \\
\hline PPh pasal 21 setahun & & \\
\hline PPh pasal 21 sebulan & & \\
\hline
\end{tabular}

Sumber: Formulir 1721-A2 Januari 2017 BPK-AD Manado 
Penghasilan Tidak Kena Pajak (PTKP) adalah sebagai berikut:

Tabel 5.1

Penghasilan Tidak Kena Pajak

BPK-AD Manado

Ibu Ing, K/2

\begin{tabular}{|c|r|r|}
\hline PTKP setahun : & & \\
\hline untuk wajib pajak sendiri & 54.000 .000 & \\
\hline tambahan karena menikah & 4.500 .000 & \\
\hline tambahan 2 orang tanggungan & 9.000 .000 & \\
\hline Jumlah & & $\mathbf{6 7 . 5 0 0 . 0 0 0}$ \\
\hline
\end{tabular}

Sumber: Formulir 1721-A2 Januari 2017 BPK-AD Manado

\subsubsection{Pelaporan Pajak Penghasilan Pasal 21}

Berdasarkan hasil wawancara, prosedur pelaporan pajak pada BPK-AD Manado dimulai dari penyetoran $\mathrm{PPh} 21$, penyetoran ini dilakukan dengan mekanisme berikut:

1. penarikan Simda;

2. buat daftar pajak PPh 21 seluruh Perangkat Daerah (PD) dan disetor gelondongan;

3. buat SPM/SP2D;

4. buat E-billing;

5. setor ke bank / dapat bukti penyetoran (NTPN).

Adapun hasil di atas diperoleh dari hasil wawancara dengan responden pegawai di bidang perbendaharaan, khususnya yang menangani penyetoran pajak.

Setelah dilakukan penyetoran pajak, selanjutnya adalah pelaporan pajak. Berdasarkan hasil wawancara, prosedur pelaporan pajak penghasilan pasal 21 pegawai, dilakukan pelaporan SPT secara e-filling. Adapun pelaporan SPT dilakukan setiap tahun dan pada bulan maret menurut pegawai yang bersangkutan. Pelaporan e-filling yang dilakukan pegawai, berdasarkan pada formulir 1721 yang dibuat pada awal tahun. Formulir 1721 ini dibuat menggunakan aplikasi yang diberikan kantor pajak, dengan menginput data gaji sampai dengan bulan desember untuk tahun pajak yang telah berakhir.

\subsection{Pembahasan}

\subsubsection{Perhitungan Pajak Penghasilan Pasal 21}

Penelitian ini membahas tentang analisis perhitungan dan pelaporan pajak penghasilan pasal 21 wajib pajak orang pibadi pada Badan Pengelola Keuangan dan Aset Daerah Kota Manado. Data yang diperoleh dengan cara wawancara yaitu data pembayaran gaji pegawai negeri sipil BPK-AD Manado. Penghasilan dan gaji yang diterima pegawai pada Badan Pengelola Keuangan dan Aset Daerah (BPK-AD) Kota Manado, didasarkan atas status pegawai/golongan, gaji pokok dan tunjangan-tunjangan. Perhitungan $\mathrm{PPh}$ pasal 21 atas penghasilan pegawai tetap dengan berdasarkan Undang-undang nomor 36 tahun 2008 diperoleh dengan mekanisme berikut :

1. Penghasilan Kena Pajak (PKP) dikalikan dengan tarif pasal 17 Undang-Undang Pajak Penghasilan yaitu dikalikan dengan tarif pajak sebesar 5\%;

2. Penghasilan Kena Pajak diperoleh dari penghasilan neto setahun dikurangi dengan Penghasilan Tidak Kena Pajak (PTKP) setahun yang telah diatur dalam Peraturan Menteri Keuangan No. 101 /PMK.010/2016; 
3. Penghasilan neto didapat dari penghasilan bruto dikurangi dengan biaya jabatan $5 \%$ dari penghasilan bruto dan iuran pensiun $4,75 \%$ dari gaji pokok yang dibayar sendiri oleh pegawai;

4. Penghasilan bruto yaitu gaji pokok ditambah tunjangan istri, tunjangan anak, tunjangan fungsional umum, dan tunjangan eselon serta tunjangan beras.

5 .

Tabel 6

Perhitungan PPh 21 Pegawai Tetap

Ibu Ing, K/2

\begin{tabular}{|l|r|r|}
\hline \multicolumn{3}{|c|}{ Perhitungan PPh 21 oleh BPK-AD Manado } \\
\hline penghasilan: & & \\
\hline gaji pokok & Rp 2.810.200 & \\
\hline tunjangn istri/smi & 281.020 & \\
\hline tunjangan anak & 112.408 & \\
\hline tunj. Fung. Umum & 185.000 & \\
\hline tunj. Beras & 289.680 & \\
\hline penghasilan bruto & & 3.678 .308 \\
\hline pengurangan : & 183.915 & \\
\hline biaya jabatan (5\%x3.678.308) & 133.484 & \\
\hline Iuran pensiun (4,75\%x2.810.200) & & 3.360 .909 \\
\hline penghasilan neto sebulan & & 40.330 .908 \\
\hline penghasilan neto setahun & & 67.500 .000 \\
\hline PTKP & & -27.169 .092 \\
\hline penghasilan kena pajak & & -1.358 .454 \\
\hline PPh pasal 21 setahun (5\%x-27.169.092) & & $\mathbf{- 1 1 3 . 2 0 4}$ \\
\hline PPh pasal 21 sebulan & & \\
\hline
\end{tabular}

Sumber: data diolah dari daftar gaji BPK-AD Manado

Penghasilan Tidak Kena Pajak (PTKP) adalah sebagai berikut:

Tabel 6.1

Penghasilan Tidak Kena Pajak

Ibu Ing, K/2

\begin{tabular}{|c|r|l|}
\hline PTKP setahun : & & \\
\hline untuk wajib pajak sendiri & 54.000 .000 & \\
\hline tambahan karena menikah & 4.500 .000 & \\
\hline tambahan 2 orang tanggungan & 9.000 .000 & \\
\hline Jumlah & & $\mathbf{6 7 . 5 0 0 . 0 0 0}$ \\
\hline
\end{tabular}

Sumber: data diolah dari daftar gaji BPK-AD Manado

Perhitugan PPh 21 yang dilakukan BPK-AD Manado telah sesuai dengan peraturan perpajakan terbaru, namun penginputan gaji dan tunjangan-tunjangan serta biaya jabatan dan iuran pensiun mengalami kelebihan angka. Kelebihan ini dapat menyebabkan jumlah $P P h 21$ yang terutang bertambah. Meskipun demikian, jumlah PTKP lebih besar daripada penghasilan neto setahun pegawai. Sehingga jumlah $\mathrm{PPh} 21$, baik yang dilakukan oleh BPK- 
AD Manado maupun berdasarkan Undang-undang nomor 36 tahun 2008 adalah nihil. Dengan demikian pegawai tidak memiliki tanggungan untuk membayar pajak.

PTKP yang digunakan sebagai pengurang penghasilan neto dalam perhitungan pajak penghasilan pasal 21 pegawai yaitu Rp54.000.000,00 (lima puluh empat juta rupiah) untuk diri wajib pajak orang pribadi, dan Rp4.500.000,00 (empat juta lima ratus ribu rupiah) tambahan untuk wajib pajak yang kawin serta Rp4.500.000,00 (empat juta lima ratus ribu rupiah) tambahan untuk setiap anggota keluarga yang menjadi tanggungan sepenuhnya, paling banyak 3 (tiga) orang untuk setiap keluarga.

Perhitungan pajak penghasilan pasal 21 atas penghasilan pegawai pada Badan Pengelola Keuangan dan Aset Daerah Kota Manado, dilakukan dengan menggunakan bantuan komputer yang akan menghitung jumlah $\mathrm{PPh} 21$ pegawai berdasarkan data rekap gaji. Data rekap gaji ini merupakan sim gaji yang dikembangkan oleh Taspen. Adapun penggunaan komputer yaitu aplikasi yang diberikan dari kantor pajak kepada BPK-AD Manado.

\subsubsection{Pelaporan Pajak Penghasilan Pasal 21}

Dalam pemotongan atau pemungutan Pajak Penghasilan Pasal 21 pegawai pada Badan Pengelola Keuangan dan Aset Daerah Kota Manado, dipungut oleh bendahara atau pemegang kas pemerintah daerah Kota Manado. Dimulai dari perhitungan dan penyetoran pajak penghasilan pasal 21 pegawai negeri sipil pada BPK-AD Manado, dilakukan oleh bendahara atau pemegang kas pemerintah. Sedangkan pelaporan PPh 21 dilakukan oleh pegawai yang bersangkutan setiap tahun.

Proses pelaporan pajak penghasilan pasal 21 pada Badan Pengelola Keuangan dan Aset Daerah (BPK-AD) Kota Manado, dimulai dari penyetoran pajak oleh bendahara atau pemegang kas pemerintah daerah. Adapun mekanisme penyetorannya adalah sebagai berikut:

1. Pada tahap awal proses pelaporan yaitu dilakukan penarikan Simda, untuk memperoleh data penetapan pajak penghasilan pasal 21. Penarikan Simda dilakukan antara tanggal 1 sampai dengan tanggal 4 bulan berjalan.

2. Setelah dibuat penarikan Simda, selanjutnya pembuatan daftar pajak $\mathrm{PPh} 21$ seluruh Perangkat Daerah (PD) Pemerintahan Kota Manado, termasuk PD BPK-AD Manado. Dengan demikian penyetoran pajak penghasilan pasal 21 disetor gelondongan bersama dengan Perangkat Daerah yang ada dalam lingkup Pemerintah Kota Manado;

3. Setelah dibuat daftar pajak penghasilan 21, selanjutnya pembuatan SPM (Surat Perintah Membayar) untuk dapat dibuat SP2D (Surat Perintah Pencairan Dana);

4. Setelah dibuat SP2D, selanjutnya dibuat E-billing untuk dapat setor pajak;

5. Setelah pembuatan E-billing, selanjutnya adalah penyetoran oleh Bank Sulut sebagai kas daerah. Sehingga diperoleh bukti penyetoran dalam bentuk Nomor Transaksi Penerimaan Negara (NTPN).

Pelaporan pajak mempunyai batas tanggal jatuh tempo, sebagaimana yang dimaksud dalam Peraturan Direktur Jenderal Pajak Nomor : PER - 31/PJ/2012 tentang pedoman teknis tata cara pemotongan, penyetoran dan pelaporan pajak penghasilan pasal 21 dan/atau pajak penghasilan pasal 26 sehubungan dengan pekerjaan, jasa, dan kegiatan orang pribadi. Pelaporan PPh 21 pegawai negeri sipil pada BPK-AD Kota Manado, dilakukan oleh pegawai yang bersangkutan, yaitu dengan cara menyampaikan SPT Tahunan secara elektronik (efilling). Dan pelaporan pajak oleh pegawai, dilakukan pada bulan maret setelah berakhirnya tahun pajak. Pengisian e-filling oleh pegawai, berdasarkan pada formulir 1721 yang dibuat oleh bendahara. 


\section{KESIMPULAN DAN SARAN \\ 5.1. Kesimpulan}

Berdasarkan hasil penelitian, kesimpulan yang dapat ditarik yaitu sebagai berikut :

1. Perhitungan Pajak Penghasilan Pasal 21 wajib pajak orang pribadi oleh Badan Pengelola Keuangan dan Aset Daerah (BPK-AD) Kota Manado belum sesuai dengan Undang-undang Nomor 36 Tahun 2008 karena jumlah yang diinput mengalami kelebihan angka yang dapat menyebabkan PPh 21 terutang bertambah;

2. Penetapan Penghasilan Tidak Kena Pajak (PTKP) yaitu sebesar Rp54.000.000,00 (lima puluh empat juta rupiah) untuk diri wajib pajak orang pribadi, dan Rp4.500.000,00 (empat juta lima ratus ribu rupiah) tambahan untuk wajib pajak yang kawin serta Rp4.500.000,00 (empat juta lima ratus ribu rupiah) tambahan untuk setiap anggota keluarga yang menjadi tanggungan sepenuhnya, paling banyak 3 (tiga) orang untuk setiap keluarga, telah sesuai dengan Peraturan Menteri Keuangan No. 101 /PMK.010/2016;

3. Hasil penyetoran PPh 21 masa pegawai pada BPK-AD Manado dilakukan oleh bendahara atau pemegang kas pemerintah daerah Kota Manado sebelum tanggal 10 bulan berikutnya, dan sesuai dengan batas waktu yang ditetapkan dalam peraturan direktur Jenderal Pajak nomor : PER - 31/PJ/2012;

4. Pelaporan Pajak Penghasilan Pasal 21 wajib pajak orang pribadi oleh pegawai Badan Pengelola Keuangan dan Aset Daerah (BPK-AD) Kota Manado, dilakukan melalui efilling paling lama akhir bulan April. Sebagaimana belum sesuai dengan peraturan perpajakan yaitu akhir bulan Maret.

\subsection{Saran}

Adapun saran untuk pegawai pada Badan Pengelola Keuangan dan Aset Daerah (BPK-AD) Kota Manado yaitu:

1. Dalam perhitungan $\mathrm{PPh} 21$ pegawai tetap pada BPK-AD Manado, sebaiknya melakukan pemeriksaan kembali sebelum menginput daftar gaji ke perhitungan $\mathrm{PPh}$ 21 agar PPh 21 terutang tidak mengalami kelebihan. Beberapa penginputan yang harus diperbaiki yaitu gaji pokok, tunjangan istri, tunjangan anak, tunjangan fungsional umum, biaya jabatan dan iuran pension. Adapun untuk tunjangan beras, telah sesuai dan pas dengan yang ada di dalam daftar gaji.

2. Untuk penetapan PTKP dapat dipertahankan sesuai dengan Peraturan Menteri Keuangan No. 101 /PMK.010/2016, dan penyetoran PPh 21 oleh bendahara pemegang kas pemerintah daerah juga harus tetap mempertahankan sistem yang sudah dijalankan dengan baik.

3. Pelaporan PPh 21 oleh pegawai pada BPK-AD Manado, harus dapat melaporkan efilling sebelum akhir bulan Maret agar tidak dikenai denda atau sanksi administrasi.

\section{DAFTAR PUSTAKA}

Dantes, Nyoman. 2012. Metode penelitian. Andi. Yogyakarta.

Direktorat Jenderal Pajak. 2017. Tarif pajak penghasilan pasal 21. https://www.onlinepajak.com/id/tarif-pajak-pph-21 Diakses Mei, 03, 2017.

Indrawati, 2015. Metode penelitian manajemen dan bisnis konvergensi teknologi komunikasi dan informasi. Refika Aditama. Bandung. 
Kementerian Keuangan Republik Indonesia. 2016. Peraturan Direktur Jenderal Pajak Nomor: PER-16/PJ/2016: Tentang pedoman teknis tata cara pemotongan, penyetoran dan pelaporan pajak penghasilan pasal 21 dan / atau pajak penghasilan pasal 26 sehubungan dengan pekerjaan, jasa, dan kegiatan orang pribadi.

Kementerian Keuangan Republik Indonesia. 2016. Peraturan Menteri Keuangan No. 101 /PMK.010/2016: Tentang penyesuaian besarnya penghasilan tidak kena pajak.

Lubis, Irsan. 2014. Mahir akuntansi pajak terapan berbasis standar akuntansi \& ketentuan pajak terbaru. Andi. Yogyakarta.

Mardiasmo, 2016. Perpajakan. Edisi terbaru. Andi. Yogyakarta.

Pangalila, Regina, 2016. Analisis Penghitungan dan Pelaporan Pajak Penghasilan Pasal 21 Pegawai Badan Pelayanan Perizinan Terpadu dan Penanaman Modal Daerah (BPPT \& PMD) Kota Bitung. Jurnal Berkala Ilmiah Efisiensi Vol.16, No.3 (2016) : jilid 8. Hal 860-869. Universitas Sam Ratulangi. Manado.

Peraturan Direktur Jenderal Pajak Nomor : PER - 31/PJ/2012 : Tentang Pedoman Teknis Tata Cara Pemotongan, Penyetoran dan Pelaporan Pajak Penghasilan Pasal 21 dan/atau Pajak Penghasilan Pasal 26 Sehubungan dengan Pekerjaan, Jasa, dan Kegiatan Orang Pribadi.

Puspita, Dian, 2013. Analisis Perhitungan, Pemotongan, Penyetoran dan Pelaporan Pajak Penghasilan Pasal 21 di PT. Surabaya Inn Berkarya. Jurnal Akuntansi UNESA Vol.1, No 2 (2013). Universitas Negeri Surabaya. Surabaya.

Republik Indonesia. Undang-Undang Nomor 28 Tahun 2007: Tentang Perubahan Ketiga atas UU RI No. 6 Tahun 1983 tentang Ketentuan Umum dan Tata Cara Perpajakan.

Republik Indonesia. Undang-Undang Nomor 36 Tahun 2008: Tentang Perubahan Keempat atas UU RI No. 7 Tahun 1983 tentang Pajak Penghasilan.

Sadeli, Lili. 2016. Dasar-dasar akuntansi. Cetakan kesepuluh. Bumi Aksara. Jakarta.

Suharsono, Agus. 2014. Ketentuan Umum Perpajakan. Graha Ilmu. Yogyakarta.

Sumarsan,Thomas. 2014. Perpajakan Indonesia. Edisi empat. Indeks. Jakarta. 